\title{
US jury split over hormone patent case ...
}

[SAN DIEGO] A federal jury in San Francisco last week failed to reach a unanimous agreement on whether Genentech Inc. had infringed a patent held by the University of California for DNA for human growth hormone, although it upheld the validity of the patent itself.

After an eight-week trial, eight of the nine jurors agreed that Genentech had infringed the university's patent (see Nature 399, 289 \& 297-298; 1999). But the required unanimous decision was blocked by a lone juror.

A further hearing will now be held in two weeks' time in federal court in San Francisco on the next phase of the case, in which university attorneys will seek a new patent infringement trial, while Genentech attorneys plan to attack the university's patent by alleging that it was obtained fraudulently.

The university seeks $\$ 400$ million in damages, which it wants tripled to $\$ 1.2$ billion because of Genentech's alleged wilful infringement. University attorneys estimate that a new trial will cost $\$ 2-3$ million. The university's legal bills already top $\$ 20$ million, but those of Genentech are said to be

considerably higher than this.

The trial has drawn particular attention in the scientific community because of dramatic testimony regarding the questionable removal of a DNA sample from a lab at the University of California at San Francisco (UCSF), conflicting testimony by leading molecular biologists, and questions about the veracity of statements in a key paper published in Nature in 1979 (Nature 281, 544-548; 1979).

In its patent infringement lawsuit filed in 1990, the university alleged that Genentech used growth hormone DNA misappropriated in 1978 from a UCSF lab to create the company's bacterial synthesis process that produced its growth hormone drugs. Genentech continues to deny the allegations, insisting that it cloned and sequenced the human growth hormone for its drug independently without using the university's DNA.

In an interview after the trial, the jury foreman, Ronald J. Losch, said the eightmember majority of the jury strongly felt that the university had proved its case. "Going through the evidence and applying the law, the conclusion was inescapable," said Losch, a

\section{.. as Seeburg faces misconduct inquiry}

[MUNICH] Germany's Max Planck Society (MPS) has begun an investigation into whether Peter Seeburg, a director at the Max Planck Institute for Medical Research in Heidelberg, is guilty of scientific misconduct following his courtroom claim that he misrepresented data in a paper published in Nature in 1979 with colleagues from the US biotechnology company Genentech (see above).

The investigation was initiated by Klaus Hahlbrock, vice-president of the society's biology section, after

Seeburg wrote to Nature and Science arguing that the paper had misrepresented experiments involved in cloning the gene responsible for producing human growth hormone.

It will be the first formal investigation to be carried out under new MPS rules for handling cases of alleged scientific misconduct introduced 18 months ago (see Nature 390, 430; 1997).

The investigation

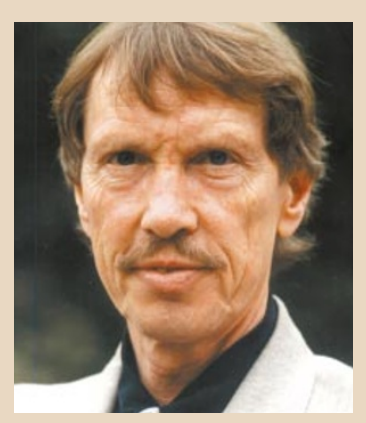

Seeburg: test case for new German misconduct rules.

committee will be chaired by Walter Ordersky, a former president of the federal court. Hahlbrock, three 'arbitrators' from different MPS sections, and the head of the MPS personnel and law department will serve on the committee, which will also call in expert witnesses.

Ordersky will report to the MPS senate "as soon as possible", and recommend sanctions, which may range from a warning to dismissal.

The MPS stresses that the investigation will not address the question of patent infringement or theft of scientific material, the subjects of the court case that ended last week. But top-ranking MPS scientists, including Hahlbrock, sensitized by a string of scientific misconduct cases in Germany, say that, had they read a book published in 1987 which described the theft, they would have asked more questions before offering Seeburg a directorship at the Institute for Medical Research in 1996.

Seeburg's position as administrative director which rotates between the institute's four directors - has been transferred to biophysicist Ken Holmes during the investigation. "It is a strain on the institute, and we are all a bit shellshocked," says Holmes. But "business is going on as usual," he stresses, with Seeburg's group of 20 or so scientists continuing to collaborate with the group led by Nobel prizewinning electrophysiologist Bert Sakmann, also a director at the institute.

Alison Abbott
San Francisco attorney with an engineering background. In deciding the case, Losch said the jury sought to concentrate on the evidence, not to get drawn into a debate over whether one scientist or another was lying.

During the trial, former Genentech researcher Peter H. Seeburg testified that, after Genentech scientists had been unable to clone the DNA for human growth hormone, they used the university's DNA, which Seeburg had spirited out of his former UCSF lab after moving to Genentech. Seeburg also testified that the DNA sample referenced in the paper "didn't exist" - testimony that has prompted him to come under investigation for scientific misconduct at the institute he now directs in Germany (see box).

But Seeburg's claims have been sharply contested by his co-authors, led by David V. Goeddel. A crucial aspect of the evidence involved whether the notebooks of Genentech scientists from 1979 showed a genetic fingerprint of independently cloned growth hormone DNA. Genentech officials and witnesses insisted that they did, while the university's scientific experts testified that they did not.

According to Losch, most of the jury who, along with the judge, received scientific tutorials during the six weeks of the trial believed that the notebooks did not provide evidence of a genetic fingerprint. But Goeddel says Genentech's scientific advisory board had examined the notebooks after the trial and felt they did show a fingerprint. "A group of scientists like that is more important than a jury," says Goeddel, now chief executive of Tularik, a company seeking genetic drugs.

As the jury began six days of deliberations, Genentech made its case public by putting parts of the notebooks on a website (see www.gene.com/labnotebooks/). Shortly afterwards, the San Francisco law firm for the university, Morrison \& Foerster, augmented its website to include the trial testimony of key witnesses and documents (see www.mofo.com).

Within hours of the decision in the case, Roche Holding announced that it was exercising its option to purchase the final onethird of Genentech's stock, under a previous pact in which Roche bought two-thirds of the stock. Genentech officials said the timing of Roche's move was a coincidence.

At the forthcoming hearing, university attorneys are to ask for a new infringement trial regarding both of Genentech's growth hormone drugs. The university also has another lawsuit pending against Genentech, accusing the company of taking some of the market from an Eli Lilly \& Co. drug created from the university's patented growth hormone DNA. Attorneys for Genentech say they may appeal against the jury's verdict validating the university's patent. RexDalton 